\title{
School Improvement Specialist Coaches Plus (SISC+) as a Catalyst for Enhancing Teachers Pedagogy Aspect in Malaysia
}

\author{
Noel Jimbai Balang, Zamri Mahamod, Nor Aishah Buang \\ Faculty of Education, National University of Malaysia (UKM), Bangi Selangor, Malaysia \\ Email: gp07311@siswa.ukm.edu.my,d-zam@ukm.edu.my, norais@ukm.edu.my
}

How to cite this paper: Balang, N. J., Mahamod, Z., \& Buang, N. A. (2020). School Improvement Specialist Coaches Plus (SISC+) as a Catalyst for Enhancing Teachers Pedagogy Aspect in Malaysia. Open Journal of Social Sciences, 8, 306-314.

https://doi.org/10.4236/jss.2020.89024

Received: April 6, 2020

Accepted: September 24, 2020

Published: September 27, 2020

Copyright () 2020 by author(s) and Scientific Research Publishing Inc. This work is licensed under the Creative Commons Attribution International License (CC BY 4.0).

http://creativecommons.org/licenses/by/4.0/

(c) (i) Open Access

\begin{abstract}
The School Improvement Specialist Coaches Plus (SISC+) programmed in Malaysia has been in operation since 2012 and is a part of the professional education team in all districts in Malaysia that helps teachers through their coaches. According to the District Transformation Programmed 3.0 (DTP 3.0), the role of SISC+ is underpinned by knowledge and skills in curriculum, pedagogy and assessment aspects. The aim of this study was therefore to identify the level of competence of SISC+ in the field of pedagogy. This study employed a descriptive design. The data has been collected via a series of questionnaires distributed nationally to 118 ICs and analyzed with version 23 of SPSS. The study used descriptive statistics with frequency, mean score, standard deviation and percentage. The results have demonstrated that Pedagogical Knowledge SISC+ competency has a mean score of 4.63 , sd $=0.469$, at a high level. The results of this study show that SISC+ is competent and knowledgeable on the pedagogical aspects of the subject. The results of this study give insight on the capabilities of SISC+ in teaching coaches in schools and in the practice of teaching and teaching of quality (T\&L). Furthermore, teachers interacted and defined the challenges in the school and social environment. It is therefore recognized that the programmed SISC+ needs to be properly understood and recognized by schools and educational institutions in order to achieve its objective of supporting teachers. Physical spaces and collaboration possibilities can improve the achievements of the coaches. The originality and value of the research is the first such research in Malaysia to explore the skills and experiences of coaches who are actively involved in the teacher instructional coaching programmed. The authority must therefore provide support and cooperation so as to ensure that SISC+ remains capable of providing teachers with good quality coaching.
\end{abstract}




\section{Keywords}

Instructional Coaching (ICs), School Improvement Specialist Coaches Plus (SISC+), District Transformation Programme 3.0 (DTP 3.0), Teaching and Learning (TnL), Malaysia Education Blueprint 2013-2025 (MEB) Coaching and Mentoring, Professional Development (PD)

\section{Introduction}

The education sector in Malaysia has had a fair share of reform measures. Many initiatives are often multi-faceted and aimed at transforming the education landscape by means of Malaysian Blue Print Education 2013-2025. The initiative was aimed at improving the results of teachers and students. Recently, an increased emphasis has been placed on educator improvements in their overall instruction and practice qualities, leading to better outcomes for students. The continued, consistent, integrated work and relevant professional learning opportunities leading to positive teacher outcomes are a challenge that school leaders should accept and take as an important responsibility (Deussen, Coskie, Robinson, \& Autio, 2018; Ahmad et al., 2016, Rinaldi, 2013).

Knight (2017) found that there was significant improvement in teaching practice as teachers gained their expertise in the subject content, teaching strategies and the management of other key elements of teaching through the development of the professionalism of teachers. In this regard, the quality of teachers' teaching and learning will improve with coaching and mentoring programmes by SISC+ or otherwise known as instructional coaches through the District Transformation Programme (DTP). SISC+ is responsible for guiding the subject panel and teachers to develop effective and quality intervention, in accordance with the Standard Operating Procedure (SOP) issued in 2019. The Ministry of Education (MOE) is committed to improving drastic examination results in line with the aspirations of MEB (2013), focusing on teachings and learning practice based on the latest pedagogy and in compliance with the educational needs and requirements of the 21 st century (Rozita, Jamian, \& Sabil, 2016). The purpose and function of SISC+ are to ensure that teachers master the most recent pedagogical aspects such as the use of information technology in teaching and learning (T\&L), the growth of the Professional Learning Community (PLC), the practice and instruction of teachers in the implementation of higher-level thought skills (HOTS) (DTP 3.0). This research is generally intended to investigate the competencies of SISC+ in pedagogical knowledge as their Key Performance Indicator (KPI).

\section{Research Objective}

One objective and one research issue to be addressed in this research, which is:

To identify SISC+ competency in the aspects of pedagogy knowledge and the 
research questions is what is the SISC+ competency in the aspect of pedagogy knowledge?

\section{Literature Review}

\subsection{SISC+ Programme}

School Improvement Specialist Coaches Plus (SISC+) or also known as Instructional Coaches (ICs) programme was introduced in 2012 to support teachers by coaching to improve T\&L in the classroom (Jusoh \& Zamri, 2016; Hobson, 2016). The instructional coach who works with coaching teachers plays the same role in other countries, in order to make T\&L more efficient and exciting (Knight, 2017; Joyce \& Shower, 2010; Torres, 2014). The role of SISC+, according to the District Transformation Programme 3.0, coaches teachers for pedagogical skills, leading and monitored implementation effectiveness and encompasses responsibility for new curricula and latest pedagogy in the classroom. The first outcome determines the SISC+ where each District Education Office will be empowered to customise the help required by the schools, including the recruitment of full-time teacher coaches. SISC+ will guide and support teachers in low-level schools. The introduction of SISC+ is intended to reduce the number of levels involved in curricula and pedagogical delivery and to provide teachers with continuous processional development (CPDs) (Ali, Wahi, \& Yamat, 2018).

According to the 2013-2025 Malaysian Education Blueprint (MEB), the SISC+ programme includes both concepts, coaching and mentoring; and is defined as a catalyst for improving TnL by developing teachers' knowledge and skills, understanding and implementing the latest educational reforms, curriculum, pedagogy and evaluation. SISC+ is required to perform both roles as teacher instructional coach (Knight, 2017; Ali, Wahi, \& Yamat, 2018; Balang, Mahamod, \& Buang, 2019; Rozita, Brahim, \& Sabil, 2016).

\subsection{Instructional Coaches}

Instructional coaches (ICs) apply to individuals on-site in schools or districts that are full-time skilled developers. ICs work with teachers to help them integrate instructional practices that are based on research. When ICs work with students, they do so with the primary aim of showing to teachers new, effective practices. Like executive coaches, ICs need to be able to unpack their customers' needs and collaborate with teachers' expectations to help teachers develop a strategy to meet their professional goals. ICs must have an outstanding range of communication skills and have the ability to empathise, listen and develop relationships and trust. Also, ICs must be highly qualified to help teachers focus on their classroom activities, as must cognitive coaches. Finally, ICs must know many scientifically proven instructional practices, just like coaches of literacy. The ICs focus on a wider range of instructional issues, sharing a variety of effective practices that can cover classroom management, improving content, specific teaching practices or formational evaluations. The ICs work closely with teach- 
ers in order to identify and incorporate investigative strategies to help students learn more efficiently and effectively (Knight, 2017; Aguilar, 2013).

\section{Methodology}

This descriptive research uses questionnaire tools distributed via the goggle form and built on the basis of the District Transformation Programme (DTP 3.0 Management Book, Ministry of Education Malaysia, MOE). A total of 23 items for both dimensions have been checked, i.e. pedagogical information has been randomly distributed. In Sarawak, Malaysia, a total of 118 SISC+ responded to the distributed questionnaire. The results of the analysis were analysed using Statistic for Social Sciences (SPSS) version 23. The study findings included only descriptive analysis consisting of mean, standard deviation, frequency and percentage. The mean score details are based on the Nunnally and Bernstein interpretations (1994) (Table 1).

\section{Finding}

Table 2 shows the frequency and percentage scores for each item for the recognition of SISC + competence levels in the pedagogical dimension calculated by twenty-three items. The results showed that all thirteen items had high scores. The results of this survey showed that item $\mathrm{C} 1$, "Guide guided teacher writing well for learning objectives" had a mean of 4.64 and a standard deviation of 0.517 whereas item C18, “'Guiding Guided Teacher', Predicting the Impact of Evidence-Based Action and Designing Appropriate Interventions", had a mean of 4.41 and a standard deviation of 0.682 . Overall, the scores indicate that SISC + competency level in pedagogy $($ mean $=4.55, \mathrm{SP}=0.491)$ among respondents was high.

\section{Discussion}

The results indicate that SISC+ competence in the field of pedagogy is high. It confirms the results of the research conducted by Jusoh \& Zamri (2016), which SISC+ specializes in providing guidance to teachers in the fields of pedagogy suited to 21 st century education needs. Researching the expectations found in the MEB (2013-2025) claimed that this country's education should be able to produce students with thinking skills, leadership skills, awareness, bilingual skills, ethics and spirituality and national identity. A coach, who is effective in guiding teachers in developing successful day-to-day teaching plans, says

Table 1. Mean score.

Number Mean value Interpretation

1) $4.01-5.00$ Very High

2) 3.01 - 4.00 Moderate High/Moderate

3) $2.01-3.00$ Low

4) $1.00-2.00$ Very Low 
Table 2. Level of pedagogical knowledge.

\begin{tabular}{|c|c|c|c|c|c|c|c|c|}
\hline No & Items & VIc & Ic & Lc & $\mathrm{C}$ & VC & Mean & $S d$ \\
\hline $\mathrm{C} 1$ & $\begin{array}{l}\text { Guides Guided Teacher (GT) to write learning } \\
\text { objectives well }\end{array}$ & $\begin{array}{l}0 \\
(0.0)\end{array}$ & $\begin{array}{l}0 \\
(0.0)\end{array}$ & $\begin{array}{l}3 \\
(2.3)\end{array}$ & $\begin{array}{l}33 \\
(25.8)\end{array}$ & $\begin{array}{l}92 \\
(71.9)\end{array}$ & 4.70 & 0.511 \\
\hline $\mathrm{C} 2$ & $\begin{array}{l}\text { Guiding GT provides effective teaching planning at the } \\
\text { student level }\end{array}$ & $\begin{array}{l}0 \\
(0.0)\end{array}$ & $\begin{array}{l}0 \\
(0.0)\end{array}$ & $\begin{array}{l}3 \\
(2.3)\end{array}$ & $\begin{array}{l}34 \\
(26.6)\end{array}$ & $\begin{array}{l}91 \\
(71.1)\end{array}$ & 4.69 & 0.514 \\
\hline C3 & Guiding GT produces activity-based learning & $\begin{array}{l}0 \\
(0.0)\end{array}$ & $\begin{array}{l}0 \\
(0.0)\end{array}$ & $\begin{array}{l}2 \\
(1.6)\end{array}$ & $\begin{array}{l}32 \\
(25.0)\end{array}$ & $\begin{array}{l}94 \\
(73.4)\end{array}$ & 4.72 & 0.485 \\
\hline $\mathrm{C} 4$ & Guides GT in terms of student focus and attention & $\begin{array}{l}0 \\
(0.0)\end{array}$ & $\begin{array}{l}0 \\
(0.0)\end{array}$ & $\begin{array}{l}3 \\
(2.3)\end{array}$ & $\begin{array}{l}35 \\
(27.3)\end{array}$ & $\begin{array}{l}90 \\
(70.3)\end{array}$ & 4.68 & 0.516 \\
\hline C5 & Guides GT in classroom management & $\begin{array}{l}0 \\
(0.0)\end{array}$ & $\begin{array}{l}0 \\
(0.0)\end{array}$ & $\begin{array}{l}4 \\
(3.1)\end{array}$ & $\begin{array}{l}35 \\
(27.3)\end{array}$ & $\begin{array}{l}89 \\
(69.5)\end{array}$ & 4.66 & 0.536 \\
\hline C6 & Guiding GT provides appropriate learning resources & $\begin{array}{l}0 \\
(0.0)\end{array}$ & $\begin{array}{l}0 \\
(0.0)\end{array}$ & $\begin{array}{l}4 \\
(3.1)\end{array}$ & $\begin{array}{l}33 \\
(25.8)\end{array}$ & $\begin{array}{l}91 \\
(71.1)\end{array}$ & 4.68 & 0.531 \\
\hline $\mathrm{C} 7$ & $\begin{array}{l}\text { Guiding GT is ranking the content based on the } \\
\text { learning objectives }\end{array}$ & $\begin{array}{l}0 \\
(0.0)\end{array}$ & $\begin{array}{l}0 \\
(0.0)\end{array}$ & $\begin{array}{l}6 \\
(4.7)\end{array}$ & $\begin{array}{l}35 \\
(27.3)\end{array}$ & $\begin{array}{l}87 \\
(68.0)\end{array}$ & 4.63 & 0.573 \\
\hline $\mathrm{C} 8$ & $\begin{array}{l}\text { Guides the GT on the subject matter knowledge of the } \\
\text { subject being taught }\end{array}$ & $\begin{array}{l}0 \\
(0.0)\end{array}$ & $\begin{array}{l}0 \\
(0.0)\end{array}$ & $\begin{array}{l}3 \\
(2.3)\end{array}$ & $\begin{array}{l}38 \\
(29.7)\end{array}$ & $\begin{array}{l}87 \\
(68.0)\end{array}$ & 4.66 & 0.524 \\
\hline C9 & $\begin{array}{l}\text { Guide High Level Thinking Skills based on GT learning } \\
\text { outcomes }\end{array}$ & $\begin{array}{l}0 \\
(0.0)\end{array}$ & $\begin{array}{l}0 \\
(0.0)\end{array}$ & $\begin{array}{l}4 \\
(3.1)\end{array}$ & $\begin{array}{l}50 \\
(39.1)\end{array}$ & $\begin{array}{l}74 \\
(57.8)\end{array}$ & 4.55 & 0.559 \\
\hline $\mathrm{C} 10$ & Guides the management of T\&L time made by GT & $\begin{array}{l}0 \\
(0.0)\end{array}$ & $\begin{array}{l}0 \\
(0.0)\end{array}$ & $\begin{array}{l}3 \\
(2.3)\end{array}$ & $\begin{array}{l}41 \\
(32.0)\end{array}$ & $\begin{array}{l}84 \\
(65.6)\end{array}$ & 4.63 & 0.531 \\
\hline $\mathrm{C} 11$ & Guides GT various T\&L techniques for each activity & $\begin{array}{l}0 \\
(0.0)\end{array}$ & $\begin{array}{l}0 \\
(0.0)\end{array}$ & $\begin{array}{l}3 \\
(2.3)\end{array}$ & $\begin{array}{l}39 \\
(30.5)\end{array}$ & $\begin{array}{l}86 \\
(67.2)\end{array}$ & 4.65 & 0.526 \\
\hline $\mathrm{C} 12$ & $\begin{array}{l}\text { Guides GT in the field of verbal inquiry based on the } \\
\text { topic being taught }\end{array}$ & $\begin{array}{l}0 \\
(0.0)\end{array}$ & $\begin{array}{l}0 \\
(0.0)\end{array}$ & $\begin{array}{l}3 \\
(2.3)\end{array}$ & $\begin{array}{l}46 \\
(35.9)\end{array}$ & $\begin{array}{l}79 \\
(61.7)\end{array}$ & 4.59 & 0.539 \\
\hline $\mathrm{C} 13$ & $\begin{array}{l}\text { Guides the GT in the formulation of formative } \\
\text { assessment }\end{array}$ & $\begin{array}{l}0 \\
(0.0)\end{array}$ & $\begin{array}{l}0 \\
(0.0)\end{array}$ & $\begin{array}{l}8 \\
(6.3)\end{array}$ & $\begin{array}{l}49 \\
(38.3)\end{array}$ & $\begin{array}{l}71 \\
(55.5)\end{array}$ & 4.49 & 0.615 \\
\hline $\mathrm{C} 14$ & $\begin{array}{l}\text { Guides GT to design a cover of T\&L that fits the } \\
\text { subject }\end{array}$ & $\begin{array}{l}0 \\
(0.0)\end{array}$ & $\begin{array}{l}0 \\
(0.0)\end{array}$ & $\begin{array}{l}5 \\
(3.9)\end{array}$ & $\begin{array}{l}34 \\
(26.6)\end{array}$ & $\begin{array}{l}89 \\
(69.5)\end{array}$ & 4.66 & 0.553 \\
\hline $\mathrm{C} 15$ & Guide GT to write reflections well & $\begin{array}{l}0 \\
(0.0)\end{array}$ & $\begin{array}{l}0 \\
(0.0)\end{array}$ & $\begin{array}{l}3 \\
(2.3)\end{array}$ & $\begin{array}{l}36 \\
(28.1)\end{array}$ & $\begin{array}{l}89 \\
(69.5)\end{array}$ & 4.67 & 0.519 \\
\hline $\mathrm{C} 16$ & $\begin{array}{l}\text { Guides GT to identify strengths and weaknesses in } \\
\text { T\&L after lesson }\end{array}$ & $\begin{array}{l}0 \\
(0.0)\end{array}$ & $\begin{array}{l}0 \\
(0.0)\end{array}$ & $\begin{array}{l}4 \\
(3.1)\end{array}$ & $\begin{array}{l}32 \\
(25.0)\end{array}$ & $\begin{array}{l}92 \\
(71.9)\end{array}$ & 4.69 & 0.529 \\
\hline $\mathrm{C} 17$ & Guiding GT determines improvement in T\&L. & $\begin{array}{l}0 \\
(0.0)\end{array}$ & $\begin{array}{l}0 \\
(0.0)\end{array}$ & $\begin{array}{l}2 \\
(1.6)\end{array}$ & $\begin{array}{l}36 \\
(28.1)\end{array}$ & $\begin{array}{l}90 \\
(70.3)\end{array}$ & 4.69 & 0.498 \\
\hline $\mathrm{C} 18$ & $\begin{array}{l}\text { Guides GT to predict the effects of action based on } \\
\text { evidence and plan appropriate interventions }\end{array}$ & $\begin{array}{l}0 \\
(0.0)\end{array}$ & $\begin{array}{l}0 \\
(0.0)\end{array}$ & $\begin{array}{l}7 \\
(5.5)\end{array}$ & $\begin{array}{l}48 \\
(37.5)\end{array}$ & $\begin{array}{l}73 \\
(57.0)\end{array}$ & 4.52 & 0.602 \\
\hline $\mathrm{C} 19$ & $\begin{array}{l}\text { Guides GT using reflection notes for improvement } \\
\text { purposes }\end{array}$ & $\begin{array}{l}0 \\
(0.0)\end{array}$ & $\begin{array}{l}0 \\
(0.0)\end{array}$ & $\begin{array}{l}3 \\
(2.3)\end{array}$ & $\begin{array}{l}41 \\
(32.0)\end{array}$ & $\begin{array}{l}84 \\
(65.6)\end{array}$ & 4.63 & 0.531 \\
\hline $\mathrm{C} 20$ & $\begin{array}{l}\text { Guiding GT detects T\&L weakness through reflection } \\
\text { notes }\end{array}$ & $\begin{array}{l}0 \\
(0.0)\end{array}$ & $\begin{array}{l}0 \\
(0.0)\end{array}$ & $\begin{array}{l}4 \\
(3.1)\end{array}$ & $\begin{array}{l}44 \\
(34.4)\end{array}$ & $\begin{array}{l}80 \\
(62.5)\end{array}$ & 4.59 & 0.553 \\
\hline $\mathrm{C} 21$ & Guiding GT provides continuous reflection notes & $\begin{array}{l}0 \\
(0.0)\end{array}$ & $\begin{array}{l}0 \\
(0.0)\end{array}$ & $\begin{array}{l}6 \\
(4.7)\end{array}$ & $\begin{array}{l}49 \\
(38.3)\end{array}$ & $\begin{array}{l}73 \\
(57.0)\end{array}$ & 4.52 & 0.588 \\
\hline $\mathrm{C} 22$ & $\begin{array}{l}\text { Guides GT to identify strengths and weaknesses in } \\
\text { T\&L }\end{array}$ & $\begin{array}{l}0 \\
(0.0)\end{array}$ & $\begin{array}{l}0 \\
(0.0)\end{array}$ & $\begin{array}{l}2 \\
(1.6)\end{array}$ & $\begin{array}{l}44 \\
(34.4)\end{array}$ & $\begin{array}{l}82 \\
(64.1)\end{array}$ & 4.63 & 0.517 \\
\hline \multirow[t]{2}{*}{$\mathrm{C} 23$} & $\begin{array}{l}\text { Guiding GT determines the topic for further study } \\
\text { after reflection }\end{array}$ & $\begin{array}{l}0 \\
(0.0)\end{array}$ & $\begin{array}{l}0 \\
(0.0)\end{array}$ & $\begin{array}{l}11 \\
(8.6)\end{array}$ & $\begin{array}{l}44 \\
(34.4)\end{array}$ & $\begin{array}{l}73 \\
(57.0)\end{array}$ & 4.48 & 0.652 \\
\hline & Overall & & & & & & 4.63 & 0.469 \\
\hline
\end{tabular}


(Norhasma \& Nurahimah, 2019; Said, Brahim, \& Sabil, 2016), as this is the "key" to the success of a SISC+ that can result in successful feedback on teaching quality and student achievement.

It is advisable that the teachers trained to cooperate fully to improve the quality of the teachings in the aim of strengthening the internal professionalism of SISC+. Teachers are therefore encouraged to accept the views and opinions of teaching professionals. The willingness to teach is a key element in ensuring synergies between SISC+ and teachers, according to Balang, N, Mahamod, and Buang (2019). This is consistent with Allen, Pianta, Gregory, Mikami \& Lun (2011) who states that their willingness to accept several aspects of guidance particularly in recent pedagogy, such as using technology in their lessons, is the basis for a success in teacher coaching.

In addition to the research conducted by (Teemant et al., 2011), SISC+ is required to constantly build autonomous support in the latest pedagogy to effectively guide teachers in order to obtain teacher confidence. A major aspect of SISC+ is to help teachers write lesson plans effectively every day and to evaluate aspects of the strengths and weaknesses of teachers (Tshabalala, 2013). Futhermore, Ware \& Kitsanis (2015) clarified that one of the reasons for the lack of trust of teachers in instructional coaches is the lack of expertise in pedagogy content knowledge (Borman \& Feger, 2006).

Teachers and school variables are essential measures of enhancing the synergy of SISC+. The SISC+ Professional Learning Community (PLC) and teachers should be able to form collaborative and trusting academic teams. Teachers should collaborate with SISC+ for guidance (Gill, Kostiw, \& Stone, 2010). A good relationship would build resilience between SISC+ and teachers. As far as pedagogy is concerned, the SISC+ dimension will direct teachers to be more positive about the quality of information, the use of technology in teaching (Aguilar, 2011). A few SISC+ have not mastered the contents pedagogy of the topic (Williams, 2017). This finding reinforces the claim that teachers who still have phobia, fears or negatives accept change because they prefer to rely on the old methods of textbooks, books or written materials on white boards alone (Tofade, 2010).

SISC+ professionalism does not simply mean the professionalism but also the holistic. Since SISC+ is responsible for leading teachers to change the T\&L quality, SISC+ balances the integration of three key elements of knowledge, skills and values. This is important, because SISC+ predicts quality teaching and outstanding achievements in international standards such as trends in international mathematics and science study (TIMSS) and the International Assessment Programme PISA, to ensure a smooth and efficient transformation of knowledge (Gonzalez del Castillo, 2015; Rinaldi, 2013). Good values are also important for SISC+ to enable teachers to translate them into life or classroom teaching in line with the philosophy of national education, which is designed to produce physically and emotionally, intellectually and social aspect (MOE). 
To make SISC+ more effective, it is important that SISC+ not only enhances its coaching capabilities, but also enhances its standing as an instructor, quality of the information, master's technology and professional teaching methods, masters pedagogical fitness, self-directed professionals, learning interests and questioning skills (Torres, 2014). SISC+ studies are crucial to enrich the wealth of instructional coaching. The overall role of the study is to form a foundation for education, teachers, schools, education ministries, parents and communities to remain steadfast, and continuously search for ideas and solutions to the excellent education system (Hobson, 2016).

\section{Conclusion}

Education has a hard future and needs to be rigorous, systemic and holistic. Collaborative efforts between educators and all stakeholders are therefore imperative to mobilize for student benefit. Whilst the impact of SISC+ coaching is shown to improve T\&L quality, the stakeholders should always provide support and opportunities for SISC+ to provide different courses, workshops and improve the coaching quality. SISC+ is not a simple job as it requires a long and clear way to shift teacher's attitudes and perceptions. The SISC+ programme therefore needs to continue improving teaching quality in classrooms (Desimone, 2016; Williams, 2017; Balang, Mahamod \& Buang, 2019).

Since this study was a descriptive analysis, further research is required to better explain what coaches need to learn and be able to do while communicating with teachers. The drawback of our study is that it has only been tested through the survey. Additional research is required to analyse and expand on our results while examining specifically how a good pedagogy can affect teachers' T\&L.

\section{Conflicts of Interest}

The authors declare no conflicts of interest regarding the publication of this paper.

\section{References}

Aguilar, E. (2011). Coaching Teachers: What You Need to Know. http://www.edweek.org/tm/articles/2011/02/15/tln_coaching.html

Aguilar, E. (2013). The Art of Coaching: Effective Strategies for School Transformation. San Francisco, CA: Jossey-Bass.

Ahmad, S. M., Radzuwan, A. R., Kamariah, Y., \& Safawati, B. Z. (2016). Exploring the School Improvement Specialist Coaches' Experience in Coaching English Language Teachers. International Arab World English Journal, 7, 243-255. https://doi.org/10.24093/awej/vol7no3.19

Ali, Z. B. M., Wahi, W., \& Yamat, H. (2018). A Review of Teacher Coaching and Mentoring Approach. International Journal of Academic Research in Business and Social Sciences, 8 , 504-524.

https://hrmars.com/papers_submitted/4609/A_Review_of_Teacher_Coaching_and_Me ntoring_Approach.pdf

Allen, J. P., Pianta, R. C., Gregory, A., Mikami, A. Y., \& Lun, J. (2011). An Interac- 
tion-Based Approach to Enhancing Secondary Schools Instruction and Student Achievement. Science, 333, 1034-1037. https://doi.org/10.1126/science.1207998

Balang, N., Mahamod, Z., \& Buang, N. (2019). Blended Coaching and Coaching Curve Approaches in Enhancing Teaching Competency: A Case Study. Creative Education, 10, 2718-2729. https://doi.org/10.4236/ce.2019.1012198

Borman, J., \& Feger, S. (2006). Instructional Coaching: Key Themes from Literature. http://www.brown.edu/academics/education-alliance/sites/brown.edu.academic.educat ion-alliance/files/publication/TL-Coaching-Lit-review.pdf

Desimone, L., \& Pak, K. (2016). Instructional Coaching as High-Quality Professional Development. Columbus, $\mathrm{OH}$ : The College of Education and Human Ecology, The Ohio State University. https://doi.org/10.1080/00405841.2016.1241947

Deussen, T., Coskie, T., Robinson, L., \& Autio, E. (2018). “Coach” Can Mean Many Things: Five Categories of Literacy Coaches in Reading First (Issues \& Answers Report, REL 2007-No 005). Washington DC: Department of Education, Institute of Education Sciences, National Center for Education Evaluation and Regional Assistance Northwest.

Gill, J., Kostiw, N., \& Stone, S. (2010). Coaching Teacher in Effective Instruction: A Victorian Perspective. Literacy Learning: The Middle Years, 18, 49-53.

Gonzalez del Castillo, A. (2015). Cognitive Coaching as a Form of Professional Development in a Linguistically Diverse School. Doctoral Dissertation, ProQuest Dissertation and Theses Global (UMI No. 3705178).

Hobson, A. J. (2016). Judgementoring and How to Avert It: Introducing ONSIDE Mentoring for Beginning Teachers. International Journal of Mentoring and Coaching in Education, 5, 87-110. https://doi.org/10.1108/IJMCE-03-2016-0024

Joyce \& Shower (2010). Instruction Supervision: A Behaviour System. Boston, MA: Allyn and Bacon.

Jusoh, S., \& Mahamod, Z. (2016). Tanggapan, Amalan dan Keberkesanan Bimbingan Pegawai SISC+ dari Perspektif Guru Bahasa Melayu. Prosiding Seminar Pascasiswazah Pendidikan Kebangsaan Malaysia.

Knight, J. (2017). Instructional Coaching for Implementing Visible Learning: A Model for Translating Research into Practice. Thousand Oaks, CA: Corwin. https://doi.org/10.3390/educsci9020101

Malaysia Educational Blueprint (MEB) (2013). 2013-2015: Pendidikan Prasekolah Hingga Lepas Menengah. Putrajaya: Kementerian Pendidikan Malaysia.

Norhasma, W., \& Yusoff, N. M. (2019). SKPMg2 (Standard 4) as Tools to Upgrade Teachers Teaching Quality. Journal of Educational Research and Indigenous Studies, 1, 1-9. http://www.jerisjournal.com

Rinaldi, L. (2013). The Effects of Learning about the Five States of Mind on Elementary Children in Grades 3, 4 and 5. Doctoral Dissertation, ProQuest Dissertations and Theses (UMI No. 3591907).

Said, R. R., Brahim, M., \& Sabil, A. M. (2016). Bimbingan dan Pementoran Berfokus oleh SISC+ Bahasa Melayu: Impak Terhadap Kualiti Pengajaran Guru Bahasa Melayu di Sekolah-Sekolah Menengah Daerah Samarahan, Sarawak. Jurnal Pendidikan Malaysia, 41, 131-139. http://ejournals.ukm.my/jpend/article/view/16017

Said, R. R., Jamian, A. R., \& Sabil, A. M. (2016). Pengetahuan dan Kefahaman Skop Pengajaran dan Pembelajaran Bahasa Melayu dalam Kalangan Jurulatih Pakar Pembangunan Sekolah (SISC+). International Journal of Education and Training, 2, 1-9.

http://www.injet.upm.edu.my 
Teemant, A., Wink, J., \& Tyra, S. (2011). Effects of Coaching on Teacher Use of Sociocultural Instructional Practices. Teaching and Teacher Education, 27, 683-693. https://doi.org/10.1016/j.tate.2010.11.006

Tofade, T. (2010). Coaching Younger Practitioners and Students Using Components of the Co-Active Coaching Model. American Journal of Pharmaceutical Education, 74, 1-5. https://doi.org/10.5688/aj740351

Torres, A. C. (2014). Is This Work Sustainable? Teacher Turnover and Perceptions of Workload in Charter Management Organization. Urban Education, 51, 891-914. https://doi.org/10.1177/0042085914549367

Tshabalala, T. (2013). Teachers Perception towards Classroom Instructional Supervision: A Case Study of Nkayi District in Zimbabwe. http://ijsse.com/sites/default/files/issues/2013/v4i1/paper/Paper-3.pdf

Ware, \& Kitsanis, E. D. (2015). Supervising Instruction: Differentiating for Teacher Success. Norwood, MA: Christopher Gordon.

Williams, B. (2017). High Impact Instruction. Upper Saddle River, NJ: Prentice Hall. 